\title{
The Statistical Analyses Of The Study "Sufentanil Sublingual Tablet System (SSTS) For The Management Of Postoperative Pain After Major Abdominal And Gynecological Surgery Within An ERAS Protocol: An Observational Study" [Response To Letter]
}

This article was published in the following Dove Press journal: Journal of Pain Research

\section{Stefano Turi \\ Francesco Deni \\ Gaetano Lombardi (D) \\ Marilena Marmiere (D) \\ Francesco Giuseppe Nisi \\ Luigi Beretta}

Dipartimento di Anestesia, Ospedale San Raffaele, Milano, Italy
Correspondence: Stefano Turi

Department of Anesthesiology, VitaSalute, University, San Raffaele Hospital,

Via Olgettina 60, Milan 20132, Italy

Tel + 390226432656

Email turi.stefano@hsr.it

\section{Dear editor}

We thank Wang and Miao $^{1}$ for their interest in our recent publication ${ }^{2}$ and the appreciation of our work.

We agree with them on the need of using repeated-measures analysis to evaluate pain intensity at different timepoints.

We acknowledge that, for the sake of brevity, our manuscript did not properly clarify the statistical methods used for the analysis and we take this opportunity to better explain them.

We performed a repeated measure analysis of variance (ANOVA) to compare pain intensity on different time points. The analysis resulted statistically significant $(p<0.01)$. Afterwards, we performed multiple comparisons using the error deriving from the ANOVA for repeated measures, which turned out statistically significant $(p<0.01)$.

In addition, we used the paired $t$-test to compare pain intensity on day 0 (baseline) and day 3 , as indicated in the recent publication (median NRS 6 to $0, p<0.01)^{2}$

\section{Disclosure}

The authors report no conflicts of interest in this communication.

\section{References}

1. Wang X, Miao S. The statistical analyses of the study "Sufentanil Sublingual Tablet System (SSTS) for the management of postoperative pain after major abdominal and gynecological surgery within an ERAS protocol: an observational study"[Letter]. J Pain Res. 2019;12:2723-2724. doi:10.2147/JPR. S228372

2. Turi S, Deni F, Lombardi G, Marmiere M, Nisi FG, Beretta L. Sufentanil Sublingual Tablet System (SSTS) for the management of postoperative pain after major abdominal and gynecological surgery within an ERAS protocol: an observational study. J Pain Res. 2019;12:2313-2319. doi:10.2147/JPR. S214600 
Dove Medical Press encourages responsible, free and frank academic debate. The content of the Journal of Pain Research 'letters to the editor' section does not necessarily represent the views of Dove Medical Press, its officers, agents, employees, related entities or the Journal of Pain Research editors. While all reasonable steps have been taken to confirm the content of each letter, Dove Medical Press accepts no liability in respect of the content of any letter, nor is it responsible for the content and accuracy of any letter to the editor.

Journal of Pain Research

Dovepress

\section{Publish your work in this journal}

The Journal of Pain Research is an international, peer reviewed, open access, online journal that welcomes laboratory and clinical findings in the fields of pain research and the prevention and management of pain. Original research, reviews, symposium reports, hypothesis formation and commentaries are all considered for publication. The manuscript management system is completely online and includes a very quick and fair peer-review system, which is all easy to use. Visit http:// www.dovepress.com/testimonials.php to read real quotes from published authors.

Submit your manuscript here: https://www.dovepress.com/journal-of-pain-research-journal 